Olena Chygryn,

Ph.D., Associate Professor, Sumy State University, Ukraine

iD ORCID ID, 0000-0002-4007-3728,

email: o.chygryn@econ.sumdu.edu.ua

Yurii Bilan,

Dc. Sc., Professor, Sumy State University, Ukraine

ORCID ID, 0000-0003-0268-009X,

email: y.bilan@kmm.sumdu.edu.ua

Aleksy Kwilinski,

Dr. Sc., The London Academy of Science and Business, United Kingdom

(iD ORCID ID, 0000-0001-6318-4001,

email: a.kwilinski@london-asb.co.uk

Correspondence author: o.chygryn@econ.sumdu.edu.ua

\title{
STAKEHOLDERS OF GREEN COMPETITIVENESS: INNOVATIVE APPROACHES FOR CREATING COMMUNICATIVE SYSTEM
}

Abstract. The issue of stakeholder activity and collaboration for developing and promoting the green competitiveness of enterprises are nowadays relevant and play a significant role in creating competitive advantages. Systematization literary sources prove that economic activity is characterizing by specific relationships between a wide set of stakeholders, the effective communicative system can bring potential benefits to all parties and stakeholders have specific expectations regarding various aspects of the enterprises' operation: organizational, economic, social, environmental etc. The main objective of the article is creating the preconditions for building the stakeholder communication system for promoting the green competitiveness of the company and assessing by stakeholders the results of companies' activity. The paper used scientific methods are based on logical generalization and scientific abstraction for systematizing the prerequisites for the formation of a system of communications of green competitive stakeholders; typology of green competitiveness stakeholders; formal-logical for determining the determinants and principles of effective collaboration of stakeholders of green competitiveness. For investigating the stakeholders' assessment of the green competitiveness effects was undertaken Multidimensional scaling analysis and were estimated five outcome dimensions: consumer satisfaction in green goods; efficiency of green goods production; green goods quality and cleaner production; institutional partnership; community impact. For scaling responses in survey research was used a seven-point psychometric Likert scale. A general questioning is provided for five countries: Ukraine, Poland, Romania, Slovenia, Czech Republic, and include the results of the survey the 1236 stakeholders. The results of the assessment showed that in all groups (internal and external) of stakeholder, the employees assessed results of the environmental strategies as "success» - 22,3\% and community from another group $-7,45 \%$. The stakeholder opinion is the same. That is evidence that the processes of greening stakeholder's communication are becoming wider and involve more participants. The result of the research creates the background for improving the system of green competitiveness stakeholder interaction.

Keywords: stakeholder, green competitiveness, interaction, stakeholder partnership, assessment.

Introduction. The content and structural features assessment of the stakeholders' interaction in the organization and environmentally friendly activities conduct create a basis for the enterprises' green competitiveness formation and development, provide opportunities to form additional socio, environmental and economic values (Bardach, 1998; Mills, 2002; Donaldson and Dunfee, 1999, Dzwigol et al., 2020; Kuzior et al., 2020; Kwilinski \& Kuzior, 2020; Miskiewicz \& Wolniak, 2020; Pimonenko, 2018a).

Cite as: Chygryn, O., Bilan, Y., \& Kwilinski, A. (2020). Stakeholders of Green Competitiveness: Innovative Approaches for Creating Communicative System. Marketing and Management of Innovations, 3, 358370. https://doi.org/10.21272/mmi.2020.3-26 
0., Chygryn, Y., Bilan, A., Kwilinski. Stakeholders of Green Competitiveness: Innovative Approaches for Creating Communicative System

Stakeholders effective collaboration is vital in the implementation for environmentally oriented projects and programs, development of innovation, social policy, resource conservation and environmental policies (Van Horn, 2001; Bryson, 2002; Chygryn, 2016; Dalevska et al., 2019; Kwilinski et al., 2020). The green competitiveness of the company is a complex category, represented by the economic, marketing, environment, social and corporate determinants, which reflect the results of enterprises activity on the market. At the same time, understanding and perception by all groups of stakeholder's essence and effects of companies' activity are vital for promotion their activity. The goal of the paoer is creating the preconditions for a stakeholder communication system for promoting the green competitiveness of the company and assessing by stakeholders the results of companies' activity.

Literature review. According to R. Freeman (Freeman, 2010) stakeholder theory is based on three main points:

1. Economic activity is characterized by the presence of specific relationships between enterprises and their stakeholders. At the same time, there is a relationship between the stakeholders' activities.

2. Interconnection and interdependence can bring potential benefits to all parties.

3. Each stakeholder have their specific expectations regarding various aspects of the enterprises' operation: organizational, economic, social, environmental, etc.

The stakeholder theory study (Grimble, 1996; Scott, 2000; Pimonenko, 2018c; Chygryn, 2018b; Boiko et al., 2019; Saluga et al., 2020; Savchenko et al., 2019; Tkachenko et al., 2019) allowed us to identify key areas for research the stakeholder interaction characteristics in the context of their impact on the enterprises' green competitiveness. Thus, the important points are:

- empirical identification of existing relationships between stakeholders while ensuring the enterprises' green competitiveness;

- identification of approaches and directions for improving the stakeholders' constructive interventions;

- understanding the key stakeholders in the green competitiveness formation and development and assessing their interests;

- the identification of essential and substantive basis for mutual coordination of companies internal corporate goals, stakeholders interests and their motivation;

- tools formation for reconciling the stakeholders' green competitiveness interests, conflicts prevention and contradictions;

- formation of tools for managing green competitiveness on the constructive stakeholders' interaction basis.

It should note that using the concept of «stakeholder management» is relevant. At the same time, scientists R. Freeman and D. Gidbert (Freeman, 1987) emphasize the importance of partnerships, building a system of management, not control. In this perspective, the process of managing the green competitiveness stakeholders interaction is a synthesis of stakeholder interaction, and it is designed to ensure the stakeholders' interests and needs in a systemic coherence with the corporate business interests. The system of communication and dialogue with stakeholders is studied in the scientific literature, primarily in the framework of stakeholder theory. However, as scientists S. Hart and S. Sharma were noted (Hart, 2004), current approaches do not consider «the potential to involve stakeholders in understanding» future changes "or to remove the radical uncertainty of the ongoing knowledge development». Accordingly, these and other scientists see stakeholder engagement as an organizational capacity formed in a resource-based data presentation mode. However, despite the growing popularity of the organizational capability approach among researchers, the capabilities themselves are often seen as «black boxes» because an understanding of relevant management and organizational processes, asset positions, and evolutionary pathways is still at an early stage. Constructive stakeholders involvement in internal corporate greening processes provides and strengthens the motivation of companies to cooperate 
0., Chygryn, Y., Bilan, A., Kwilinski. Stakeholders of Green Competitiveness: Innovative Approaches for Creating Communicative System

with external public and private institutions actively, develops trusting relationships with stakeholders (Bettinazzi, 2015; Yevdokimov, 2018; Chygryn, 2018a). It is important that the stakeholders' involvement and their collaboration will facilitate the exchange of knowledge, information, access to databases and experience of leading green companies, which in turn will allow companies to improve business procedures, to expand the implementation of the green initiative (Crilly, 2012; Kassinis, 2012; Chygryn, 2018c). In addition, it will be appropriate to overcome internal corporate contradictions associated with existing shortcomings in the implementation of the green innovation, inconsistent environmental information, lack of necessary knowledge and experience (Polonsky, 1998). Besides, when companies work closely with external stakeholders, it helps to increase internal self-control, increase external oversight, and, in some cases, involve stakeholders in an internal business transaction (Crilly, 2012). It raises stakeholder awareness of firms' environmental initiatives and makes information transfer more efficient. Management concepts based on the principles of stakeholder collaboration will focus companies on the widest possible provision of stakeholder requirements when the needs of other stakeholders are satisfied while meeting the needs of consumers. Relevant companies are characterized by greater flexibility of reactions to market needs, have a positive environmental image and could increase their productivity faster and more efficiently (Pimonenko, 2018b; Dzwigol \& Dzwigol-Barosz, 2018). Their belonging largely determines peculiarities of stakeholder communications to a certain group. There are various approaches to the classification of stakeholders in the scientific literature. Scientists Porter, Clarkson and Savage (1991) identify "primary» and "secondary» stakeholders. Greenley and Foxal (1996) identify the following stakeholder groups: consumers; competitors; civil servants; shareholders; trade unions. Clarke and Clegg (1998) identify customers, employees, shareholders, and suppliers as stakeholders. Henriques and Sadorski (1999) proposed four main classifications of stakeholders: organizations; communities; regulatory authorities; mass media.

Methodology and research methods. The methodological basis of the study is the fundamental provisions of economic theory, management theory, stakeholder theory, communication theory, environmental economics. In accordance with the set of goal, the following research methods were used: logical generalization and scientific abstraction - in systematizing the prerequisites for the formation of a system of communications of green competitive stakeholders; typology of green competitiveness stakeholders; formal-logical - in determining the determinants and principles of effective collaboration of stakeholders of green competitiveness. We propose to undertake a dimensional analysis of how stakeholders of green competitiveness assess the results and effects of green strategies on the base of scientific approach represented by M. Chipulu (2019). In the process of investigation will study the five outcome dimensions are identified as consumer satisfaction in green goods; efficiency of green goods production; green goods quality and cleaner production; institutional partnership; community impact. For scaling responses in survey research, a seven-point psychometric Likert scale was used. It creates the background for examining relatedness among constituent measures on each dimension and allow obtaining the exact feedback on item transparency and user-friendliness. A general questioning is provided for five countries: Ukraine, Poland, Romania, Slovenia, Czech Republic and include the results of the survey the 1236 stakeholders. Data analysis is undertaking using the Multidimensional Scaling Analysis, which creates a map displaying the relative positions of several objects, given only a table of the distances between them. The map may consist of several dimensions. In the case of analysing the stakeholder assessment will be used five dimensions. This allowed creating a five-dimensional space common to all stakeholder groups of green competitiveness

Results. It should note that the prerequisite for constructive and effective stakeholders' collaboration to promote and develop green competitiveness are related factors to the following components. 
O., Chygryn, Y., Bilan, A., Kwilinski. Stakeholders of Green Competitiveness: Innovative Approaches for Creating Communicative System

1. The desire to communicate and collaborate. It will be ensured by clear responsibilities and powers delineation, organizational support, understanding of the important stakeholders' collaboration and communication.

2. Management and leadership features that are manifested in the interaction support between company managers and other institutions heads that make decisions about the cooperation content and areas.

3. A common goal and vision, which will be provided by a common vision and the common and agreed goals establishment for organizational activities and the green competitiveness development.

4. Transparency and trust, which will be ensured by clarity in stakeholder relations, shared responsibility and support.

5. Creating an enabling environment for cooperation, openness and understanding of the stakeholders' goals and motives.

Effective interaction of stakeholders in the formation of enterprises' green competitiveness will take place through various interaction forms (Rosokhata, 2020a). Thus, the scientific approaches generalization about the peculiarities of the stakeholders' involvement and cooperation (Bettinazzi, 2015; Crilly, 2012; Hart, 2004) allowed to identify the following forms of their interaction in the enterprises' green competitiveness formation and promotion: communications; consultancy; negotiation; collaboration (Figure 1).
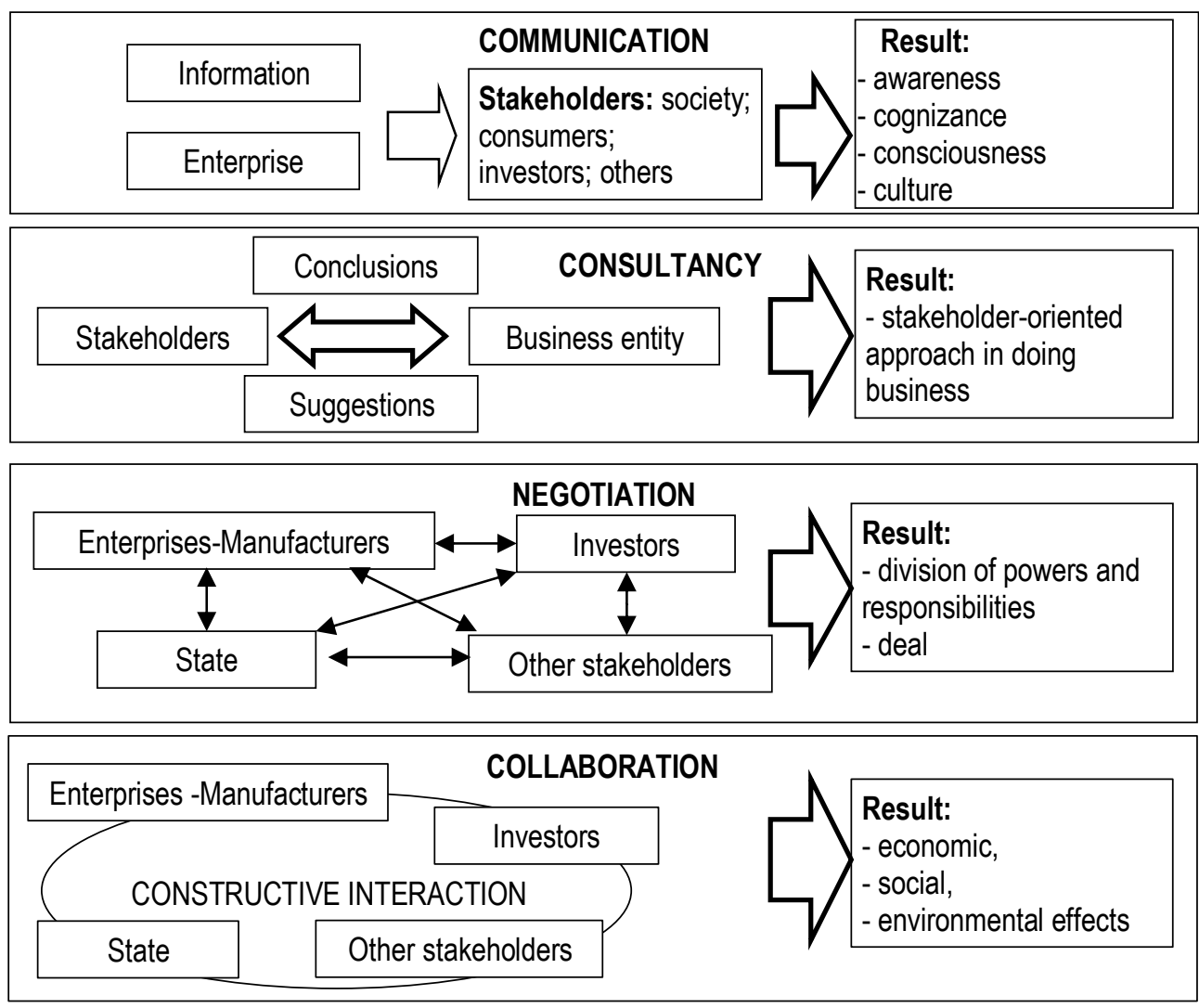

Figure 1. Forms of interaction green competitiveness stakeholders

Sources: developed by the authors. 
0., Chygryn, Y., Bilan, A., Kwilinski. Stakeholders of Green Competitiveness: Innovative Approaches for Creating Communicative System

In this case, the communication process is a one-way information transfer from the enterprise (organization) to the interested audience (society as a whole, certain groups of consumers, investors, other stakeholders, etc.). Consultation and negotiations are a bilateral mutual process, but the results expectations of these communications are different. Thus, the participants of the consultations expect their opinions, conclusions and proposals will be heard and taken into account in the formation of green strategies and development programs, in planning the implementation of environmentally friendly innovation projects, in promoting green technologies and industries etc. In turn, the negotiators expect from the interaction process of mutually beneficial agreements and a clear responsibilities division that will ensure the joint effect and results in the future. In this case, negotiations are an interactive form that will be accompanied by the contractual relations emergence. Collaboration in promoting green competitiveness is a fairly mature and comprehensive form of stakeholder interaction, where various parties plan to actively participate in certain projects and activities and seek to achieve appropriate results. It will be expressed in socio-environmental and economic effects. Accordingly, the process of collaboration differs from negotiations because negotiations can have some certain contradictions and conflicts. Thus, approaches to cooperation and collaboration often have more stable and long-term perspectives than negotiations (Rosokhata, 2020b).

In addition, it should note that the effective interaction of green competitive stakeholders is impossible without reaching a consensus. It is important in today's interconnected society, as several interrelated issues affect different segments of society with different interests. Consensus mechanisms allow many stakeholders to take an active part in decision-making processes, without leaving complex conflicting decisions to experts or others (Pfeffer, 1998; Jones, 1995; Mitchell, 1997). Stakeholders should have a systematic, broad understanding and perception of the economic activity ecological problems. At the same time, ensuring mutual communication and consensus helps them to establish a common understanding and appropriate basis for developing a solution, the results of which should satisfy all (Susniene, 2006; Mills, 2002). The practical implementation of the conceptual foundations of the interaction of green competitiveness stakeholders should be determined by specifying the appropriate ways to attract stakeholders. Table 1 shows the applied aspects of the basic form's implementation of green competitiveness stakeholders' interaction.

Table 1. Applied aspects of the green competitiveness stakeholder's interaction

\begin{tabular}{|l|l|}
\hline $\begin{array}{c}\text { Green competitiveness } \\
\text { stakeholders }\end{array}$ & \multicolumn{1}{c|}{ Features of interaction } \\
\hline Company management & $\begin{array}{l}\text { Analysis and assessment of the environmental culture level and awareness of } \\
\text { the company's management, greening of company development strategies, } \\
\text { promotion of green business projects and programs, informing shareholders and } \\
\text { staff about the results of environmental activities, conferences, round tables for } \\
\text { the media, publishing reports on corporate websites. }\end{array}$ \\
\hline Company employees & $\begin{array}{l}\text { Assessment of the involvement level and awareness of the enterprise green } \\
\text { values, environmentally oriented goals discussion and results of environmental } \\
\text { activities in the main areas, promotion of staff environmental culture. Conducting } \\
\text { weeks of environmental ethics, quarterly meetings with the company's board, } \\
\text { holding regular environmental conferences, organizing hotlines for appeals, } \\
\text { meetings with speakers on environmentally oriented topics. }\end{array}$ \\
\hline Business partners & $\begin{array}{l}\text { Involvement in joint environmental programs and activities, economic tasks } \\
\text { planning related to activities greening, involvement in training programs, public } \\
\text { declaration of stakeholders' involvement in environmental activities. }\end{array}$ \\
\hline Suppliers & $\begin{array}{l}\text { Declaration of green values, holding joint promotions about environmental and } \\
\text { resource-saving topics, creation of sectoral green associations, promotion of } \\
\text { environmentally responsible procurement, green logistics introduction. }\end{array}$ \\
\hline
\end{tabular}


0., Chygryn, Y., Bilan, A., Kwilinski. Stakeholders of Green Competitiveness: Innovative Approaches for Creating Communicative System

\begin{tabular}{|l|l|}
\hline \multicolumn{2}{|l}{} \\
\hline Communities & $\begin{array}{l}\text { Continued Table 1 } \\
\text { promotion of green and resource-saving community development projects, } \\
\text { of local environmentally oriented projects, volunteering, businesses excursions. }\end{array}$ \\
\hline Customers & $\begin{array}{l}\text { Implementation of joint programs to promote green values, implementation of } \\
\text { trade marketing green campaigns, cooperation in programs and projects related } \\
\text { to health and sustainable development, formation of teams for cooperation with } \\
\text { key customers, joint business planning of environmentally friendly projects, } \\
\text { creation centers for cooperation with green customers and consumers, creation } \\
\text { of joint environmental platforms, assessment of customer satisfaction. }\end{array}$ \\
\hline Consumers & $\begin{array}{l}\text { Assessing the consumer education level on environmental issues, research of } \\
\text { target focus groups, use of omnichannel marketing approaches in integrated } \\
\text { communications, conducting green enterprise products promotions, creating } \\
\text { hotlines for consumers, displaying green topics for the corporate website, } \\
\text { conducting enterprises tours. }\end{array}$ \\
\hline State institutions & $\begin{array}{l}\text { State programs promotion to support eco-business (granting benefits, } \\
\text { guarantees, etc.), consultations, public discussions, dialogues with state } \\
\text { regulatory agencies, advising on foreign investment in eco-activities. }\end{array}$ \\
\hline Public organizations & $\begin{array}{l}\text { Holding conferences, consultations, public discussions, partnership in the } \\
\text { implementation of joint environmentally oriented programs, membership in } \\
\text { industry and business associations. }\end{array}$ \\
\hline
\end{tabular}

Sources: developed by the authors.

Thus, in the assessing context, the processes of greening economic activity, the classification system of stakeholders in the green competitiveness formation and development will look like this. It should not that the basis for the appropriate typology formation is the features and degree of certain stakeholders influence the manufacturers' activities, the green competitiveness formation and development.

Table 2. Typology of green competitiveness stakeholders

\begin{tabular}{|c|c|c|}
\hline Classification criteria & Stakeholders types & Stakeholders \\
\hline \multirow{4}{*}{$\begin{array}{l}\text { By influence degree on } \\
\text { the processes of } \\
\text { economic activity } \\
\text { greening }\end{array}$} & Explicit (active) & $\begin{array}{l}\text { Consumers of green goods and services, owners, } \\
\text { management, regulating and controlling institutions }\end{array}$ \\
\hline & Latent (passive) & $\begin{array}{l}\text { Environmentally oriented competing companies, green } \\
\text { non-governmental organizations }\end{array}$ \\
\hline & Primary & $\begin{array}{l}\text { Manufacturers of green goods and services, local non- } \\
\text { governmental organizations }\end{array}$ \\
\hline & Secondary & $\begin{array}{l}\text { Chambers of commerce, suppliers, retailers, media, } \\
\text { scientific and educational institutions }\end{array}$ \\
\hline \multirow{3}{*}{ By subject orientation } & Market & Consumers, competitors, traders, investors \\
\hline & Social pressure & $\begin{array}{l}\text { Non-governmental environmental institutions, social and } \\
\text { other associations, societies, clubs }\end{array}$ \\
\hline & State & Regulatory and controlling state institutions \\
\hline \multirow{2}{*}{$\begin{array}{l}\text { By belonging to } \\
\text { economic activity }\end{array}$} & Internal & $\begin{array}{l}\text { Company owners, management, employees of } \\
\text { enterprises }\end{array}$ \\
\hline & External & Commercial institutions, state institutions \\
\hline \multirow{3}{*}{ By influence level } & International & $\begin{array}{l}\text { Commercial and non-commercial institutions, foreign } \\
\text { competitors, green international associations and unions }\end{array}$ \\
\hline & National & $\begin{array}{l}\text { National eco-oriented producers, domestic consumers, } \\
\text { state regulators }\end{array}$ \\
\hline & Local & Competitive local businesses, local communities \\
\hline
\end{tabular}


0., Chygryn, Y., Bilan, A., Kwilinski. Stakeholders of Green Competitiveness: Innovative Approaches for Creating Communicative System

Continued Table 2

\begin{tabular}{|l|l|l|}
\hline \multirow{5}{*}{ By terms of impact } & Financial & $\begin{array}{l}\text { Green investors, creditors, financial intermediaries, } \\
\text { environmental banks, insurance companies, stock } \\
\text { exchanges }\end{array}$ \\
\cline { 2 - 3 } & $\begin{array}{l}\text { Technological } \\
\text { (innovative) }\end{array}$ & $\begin{array}{l}\text { Technology parks, business incubators, research and } \\
\text { scientific institutions }\end{array}$ \\
\cline { 2 - 3 } & $\begin{array}{l}\text { Environmentally } \\
\text { friendly (green) }\end{array}$ & $\begin{array}{l}\text { Green consumers, businesses that have a sustainable } \\
\text { green image, non-governmental environmental } \\
\text { organizations }\end{array}$ \\
\hline
\end{tabular}

Sources: developed by the authors.

The theoretical basis generalization of the stakeholder collaboration theory allows forming the main determinants of their effective interaction for the green competitiveness formation and promotion.

1.Stakeholders must be interdependent and mutually interested. It is determined by the need to interact to achieve a common goal (that is none of them will be able to achieve on their own what the group can achieve through cooperation). Thus, it is necessary to encourage people to work together and cooperate.

2.Clear and constructive definition of values and motivation of each stakeholder in promoting environmentally friendly activities. It means that differences in values, needs and interests should not be an obstacle to meeting goals. They should be recognized, worked with and adhered to.

3.Joint or clearly differentiated responsibility for the fulfilment of obligations and for the decisions taken results. Thus, stakeholders in the implementation of environmentally oriented projects and programs should reach a consensus in the formation of final decisions and be ready to implement them.

4.Stakeholder cooperation. Thus, building consensus or cooperation must be an emergent process. In other words, decisions and results of stakeholder cooperation should be implemented flexibly.

Building effective interaction of green competitiveness stakeholders should be based on the following principles: transparency; voluntary; integration; joint targeting; mutual benefits; ecological and economic efficiency; constructiveness; equality; responsibilities; motivation; prevention. Figure 2 shows the interaction system of green competitiveness stakeholders.

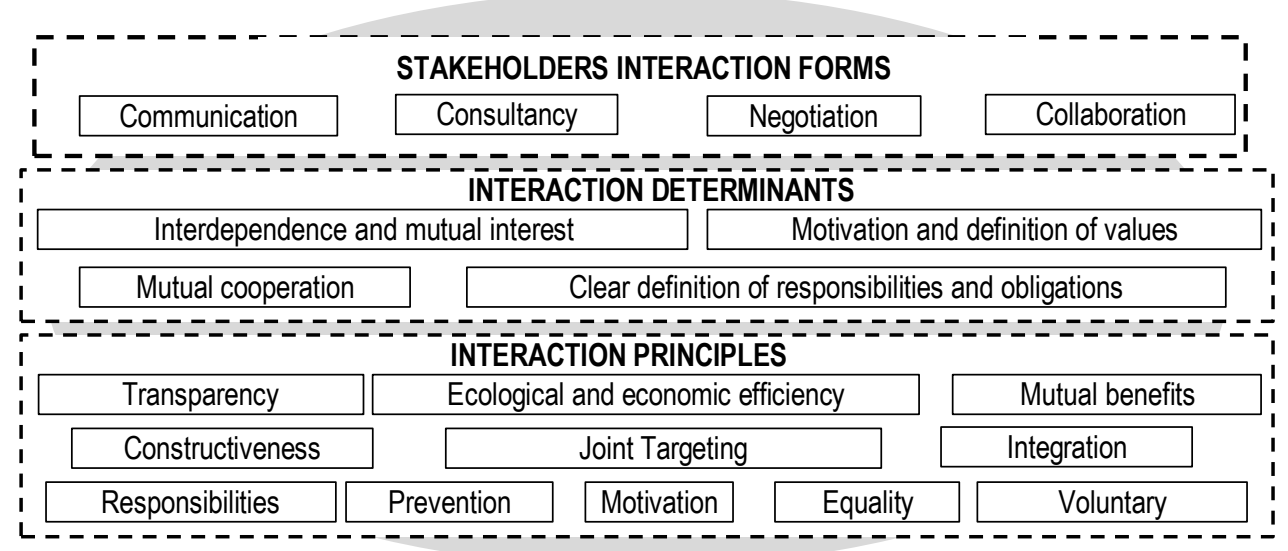

Figure 2. The interaction system of green competitiveness stakeholders

Source: developed by the authors. 
0., Chygryn, Y., Bilan, A., Kwilinski. Stakeholders of Green Competitiveness: Innovative Approaches for Creating Communicative System

It should note that the constructive interaction of green competitiveness stakeholders and reaching a consensus between them will ensure the protection of all parties in the environmentally friendly and resource-saving projects and programs implementation. It is possible if all participants make final decisions voluntarily and each party has a chance to make sure that its interests are represented. To assess the results and effects of green strategies were gathered valid data from 1236 stakeholders when were classified on groups by belonging to economic activity: internal and external (Table 3).

Table 3. Representation of stakeholders by role and success-failure type

\begin{tabular}{|c|c|c|c|c|}
\hline \multirow{2}{*}{$\begin{array}{c}\text { Category of } \\
\text { stakeholder }\end{array}$} & \multirow{2}{*}{ Type } & \multicolumn{3}{|c|}{ Type frequency by type, \% } \\
\cline { 2 - 5 } & & Success & Failure & Total \\
\hline \multirow{4}{*}{ Internal } & Stuff & $275(22,3 \%)$ & $178(14,41)$ & $523(42,31 \%)$ \\
\cline { 2 - 5 } & Manger & $150(12,15 \%)$ & $77(6,27)$ & $217(17,56 \%)$ \\
\cline { 2 - 5 } & Board of derectors & $38(3,12 \%)$ & $33(2,69)$ & $174(14,08 \%)$ \\
\cline { 2 - 5 } & Chairman of the Board & $67(5,45 \%)$ & $31(2,51)$ & $75(6,07 \%)$ \\
\hline \multirow{3}{*}{ External } & Consumers & $50(4,08 \%)$ & $168(13,65)$ & $383(30,99 \%)$ \\
\cline { 2 - 5 } & Community & $28(7,45 \%)$ & $67(5,42)$ & $87(6,96 \%)$ \\
\cline { 2 - 5 } & Institutional Stakeholders & $95(2,31 \%)$ & $21(1,92)$ & $99(8,01 \%)$ \\
\hline Total & & $703(56,86 \%)$ & $533(46,86)$ & $1236(100 \%)$ \\
\hline
\end{tabular}

Source: developed by the authors.

According to Table 3, most stakeholders represented by the internal respondents $-56,86 \%$. In all groups of stakeholders, stuff is assessing results of the environmental strategies as «success» $-22,3 \%$ and community from another group $-7,45 \%$. Figure 3 shows the results of Multidimensional Scaling Analysis for the five dimensions: consumer satisfaction in green goods (D1); efficiency of green goods production (D2); green goods quality and cleaner production (D3); institutional partnership (D4); community impact (D5).

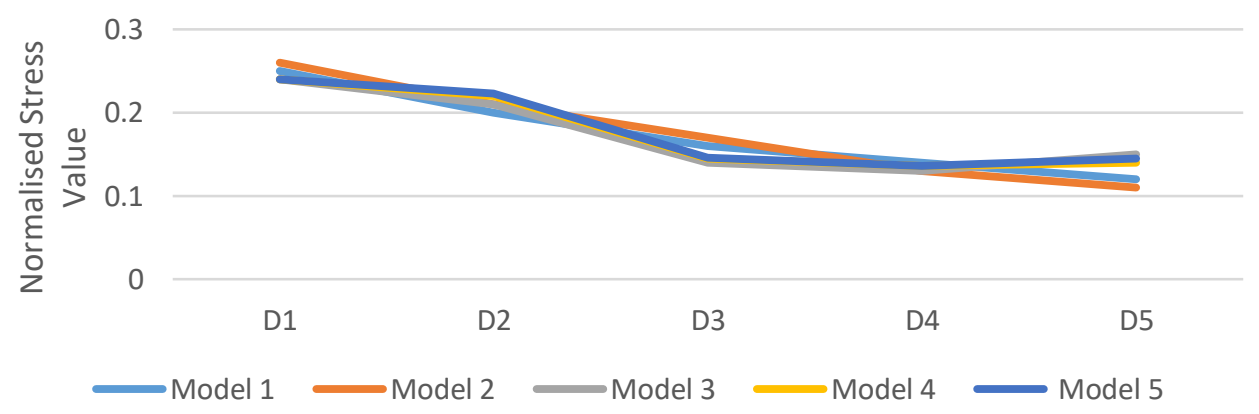

Figure 5. Results of normalized stress per MDS dimension

Source: developed by the authors.

The results in Figure 5 show that for all dimensions, the stakeholder opinion is the same. That is evidence that the processes of greening stakeholder's communication are becoming wider and involve more participants.

The formation and promotion of enterprises' green competitiveness are possible if there are clearly defined criteria for assessing its level by stakeholders. Thus, from the point of view of consumers, the basic criteria should be: 
O., Chygryn, Y., Bilan, A., Kwilinski. Stakeholders of Green Competitiveness: Innovative Approaches for Creating Communicative System

- product quality, its environmental characteristics, the possibility of recycling the product and packaging, environmental friendliness of production technology;

- features of pricing, availability of discount and bonus programs, the possibility of obtaining discounts for disposing of goods or packaging (containers);

- features of logistics and goods delivery, the possibility of purchasing online, the availability of green platforms for consumer communications;

- availability of different green goods service system.

Employees of enterprises also form a group of stakeholders interested in certain enterprise results. For assessing the level of green competitiveness, this category will act as an indicator of relevant environmentally oriented processes. So, the following will be important for employees of enterprises:

- the competitive level of wages;

- job satisfaction, faith in the corporate mission of the company, understanding of belonging to the positive changes in the environment;

- environmentally safe working conditions;

- environmentally oriented motivation.

Today, society is an active stakeholder in terms of monitoring the enterprises' impact processes to the environment. So, there are the next actual steps in this direction for society as a whole:

- enterprises environmentally oriented behaviour;

- promotion of innovative nature and resource-saving activity principles;

- quality and safety of the company products and services;

- green infrastructure development.

Conclusion. The development of innovation and green competitiveness formation is possible via the conditions of relevant green projects and programs implementation. It requires a strong additional financial support. Investors and lenders are forming a powerful stakeholders cluster. They are interested in: the level of return on green investment, which is characterized by indicators of profitability, investment profit; the level of environmentally oriented corporate responsibility; the company rising share price; features of marketing policy for the green goods and services promotion.

It should note that the company's owners (shareholders) largely determine the characteristics and effectiveness of companies. There is a theoretical approach, according to which the activities of companies' owners and managers are considered in terms of «nanoeconomy». Thus, important in green competitiveness development are:

- the gaps assessment between the shareholders and managers personal interests and the team interests, and objectively the best and most effective for this company ways to realize its environmentally friendly competitive potential;

- gaps assessment in the managers and performers remuneration;

- shift of managerial interests towards short-term. Because there is instability, which is supported by artificial means;

- high corruption level;

- market competition restriction, creation of barriers for green competitiveness development.

Thus, for assessing the greening processes and the green competitiveness level, the owners of the company will analyze company green image and green brand; company greenwashing; growth of the company's shares market value, including green shares; investment level to green projects and programs, including green investments; resource and energy intensity of economic activity.

The key guidelines definition for the main stakeholders will allow approaching the formation of various strategies and roadmaps for enterprise development, under considering and concretizing of marketing components. 
0., Chygryn, Y., Bilan, A., Kwilinski. Stakeholders of Green Competitiveness: Innovative Approaches for Creating Communicative System

Stakeholders effective interaction is possible with a clear definition of the main stakeholders' functions, which should include:

- economic, they ensure the effective profitability of environmentally friendly companies. It is important to assess the production processes of energy, material and resource intensity, the green pricing using, evaluation of environmentally friendly business projects and programs;

- managerial, it consists of the economic activity process organization, implementation environmental issues to the company strategy and policy, the environmental management system implementation, conducting an independent environmental audit;

- marketing, which are determined by using a modern tools system for the green competitiveness formation and development, green goods and services existing and potential consumers analysis, environmental products promotion, the company green image and brand formation, avoiding greenwashing.

Thus, the organizational and economic foundation formation of green competitiveness stakeholders interaction would create a basis for their constructive and effective collaboration. It would ensure the formation and strengthening of green competitive positions in the market, as well as form the environmentally friendly enterprise positive image, expand the range of green goods and services consumers.

Author Contributions: Conceptualization, Y. B., O. C., and A. K.; methodology, Y. B., O. C., and A. K.; validation, Y. B., O. C., and A. K.; formal analysis, O. C.; project administration, Y. B., O. C., and A. K.; investigation, Y. B., O. C., and A. K.; resources, Y. B., O. C., and A. K.; data curation, O. C.; writing original draft preparation, Y. B. and O. C.; writing-review and editing, Y.B. and O. C.; visualization, O. C.; supervision, O. C.; funding acquisition, Y. B., O. C., and A. K.

Funding: This research was funded by the grants from the Ministry of Education and Science of Ukraine (№ 0119U101860, № 0120U102002, №0120U102001).

\section{References}

Baranovskyi, O. I. (2020). Regulation of functional and structural transformational processes in the financial sector. Financial and credit activity: problems of theory and practice, 1(32), 292-306. [Google Scholar] [CrossRef]

Baranovskyi, O. I. (2018). Quality of the transformational processes in the financial sector of the national economy: vectors of the measurement. Financial and credit activity: problems of theory and practice, 3(26), 350-367. [Google Scholar] [CrossRef]

Bardach, E. (1998). Getting agencies to work together: The practice and theory of managerial craftsmanship. Brookings Institution Press. [Google Scholar]

Bardy, R., Rubens, A., \& Eberle, P. (2017). Soft Skills and Job Opportunities of Migrants: Systemic Relationships in the Labour Market. Business Ethics and Leadership. 1(4), 5-21. [Google Scholar]

Bettinazzi, E. L. M., \& Zollo, M. (2015, June). Stakeholder engagement and organizational experiential learning: Evidence from M\&A activities. In DRUID15 Conference (pp. 15-17). [Google Scholar]

Boiko, V., Kwilinski, A., Misiuk, M., \& Boiko, L. (2019). Competitive Advantages of Wholesale Markets of Agricultural Products as a Type of Entrepreneurial Activity: The Experience of Ukraine and Poland. Economic Annals-XXI, 175(1-2), 68-72. [CrossRef]

Bryson, J. M., Cunningham, G. L., \& Lokkesmoe, K. J. (2002). What to do when stakeholders matter: The case of problem formulation for the African American Men Project of Hennepin County, Minnesota. Public Administration Review, 62(5), 568-584. [Google Scholar] [CrossRef]

Chigrin, O., \& Pimonenko, T. (2014). The ways of corporate sector firms financing for sustainability of performance. International Journal of Ecology and Development, 29(3), 1-13. [Google Scholar]

Chipulu, M., Ojiako, U., Marshall, A., Williams, T., Bititci, U., Mota, C., ... \& Stamati, T. (2019). A dimensional analysis of stakeholder assessment of project outcomes. Production Planning \& Control, 30(13), 1072-1090. [Google Scholar] [CrossRef]

Chygryn, O. (2016). The mechanism of the resource-saving activity at joint stock companies: The theory and implementation features. International Journal of Ecology and Development, 31(3), 42-59. [Google Scholar]

Chygryn, O. (2018a). Green consumers: structure and profile. Bulletin of Sumy State University. Economics series, 4, 72 - 76.

Chygryn, O. (2018b). Green consumption: preconditions and prospects for promotion. Bulletin of Sumy State University. Economics series, 3, $82-86$. 
0., Chygryn, Y., Bilan, A., Kwilinski. Stakeholders of Green Competitiveness: Innovative Approaches for Creating Communicative System

Chygryn, O., Pimonenko, T., Luylyov, O., \& Goncharova, A. (2018). Green Bonds like the Incentive Instrument for Cleaner Production at the Government and Corporate Levels Experience from EU to Ukraine. Journal of Advanced Research in Management, 9(7), 1443-1456. [Google Scholar] [CrossRef]

Clarke, T., \& Clegg, S. (1998). Changing paradigms: The transformation of management knowledge for the 21st century. HarperCollins Business.

Clarkson, M. E. (1995). A stakeholder framework for analyzing and evaluating corporate social performance. Academy of management review, 20(1), 92-117. [Google Scholar] [CrossRef]

Crilly, D., \& Sloan, P. (2012). Corporate attention to stakeholders: Enterprise logic and an inside-out explanation. Strategic Management Journal, 33(10), 1174-1193. [CrossRef]

Dalevska, N., Khobta, V., Kwilinski, A., \& Kravchenko, S. (2019). A Model for Estimating Social and Economic Indicators of Sustainable Development. Entrepreneurship and Sustainability Issues, 6(4), 1839-1860. [CrossRef]

Donaldson, T. \& T. W. Dunfee. (1999). Ties That Bind: A Social Contracts Approach To Business Ethics. Boston: Harvard Business School Press. [Google Scholar]

Dźwigoł, H., \& Dźwigoł-Barosz, M. (2018). Scientific Research Methodology in Management Sciences. Financial and Credit Activity: Problems of Theory and Practice, 2(25), 242-237. [CrossRef]

Dzwigol, H., Dzwigol-Barosz, M., Miskiewicz, R., \& Kwilinski, A. (2020). Manager Competency Assessment Model in the Conditions of Industry 4.0. Entrepreneurship and Sustainability Issues, 7(4), 2630-2644. [CrossRef]

Freeman, R. E. (2010). Strategic management: A Stakeholder approach. Cambridge: Cambridge University Press. [Google Scholar]

Freeman, R. E., \& D. Gilbert. (1987). Managing stakeholder relations. Business and society: dimensions of conflict and cooperation. Toronto, 397-422.

Greenley, G. E., \& Foxall, G. R. (1996). Consumer and nonconsumer stakeholder orientation in UK companies. Journal of Business research, 35(2), 105-116. [Google Scholar] [CrossRef]

Grimble, R., \& Wellard, K. (1997). Stakeholder methodologies in natural resource management: a review of principles, contexts, experiences and opportunities. Agricultural systems, 55(2), 173-193. [Google Scholar] [CrossRef]

Hart, S. L., \& Sharma, S. (2004). Engaging fringe stakeholders for competitive imagination. Academy of Management Perspectives, 18(1), 7-18. [Google Scholar] [CrossRef]

Henriques, I., \& Sadorsky, P. (1999). The relationship between environmental commitment and managerial perceptions of stakeholder importance. Academy of management Journal, 42(1), 87-99. [Google Scholar] [CrossRef]

Jay Polonsky, M., \& Ottman, J. (1998). Stakeholders' contribution to the green new product development process. Journal of Marketing Management, 14(6), 533-557. [Google Scholar] [CrossRef]

Jones, T. M. (1995). Instrumental stakeholder theory: A synthesis of ethics and economics. Academy of management review, 20(2), 404-437. [Google Scholar] [CrossRef]

Kassinis, G. I., \& Soteriou, A. C. (2008). Quality, environmental practices and customer satisfaction in services. Sustainable innovation and entrepreneurship, 227-247. [Google Scholar]

Kuzior, A., Kwilinski, A., \& Tkachenko, V. (2019). Sustainable development of organizations based on the combinatorial model of artificial intelligence. Entrepreneurship and Sustainability, 7(2), 1353-1376. [Google Scholar] [CrossRef]

Kuznyetsova A. Ya., Zherebylo I. V., Klipkova O. I., Kozmuk N. I. (2019). Creation of the value of national enterprises with the help of the innovation centers in the cluster formations. Financial and credit activities: problems of theory and practice, 2(29),

391-402. [Google Scholar] [CrossRef]

Kuznyetsova, A. Y., \& Klishchuk, O. V. (2017). Theoretical conception of price stability targeting arrangement: investigation of basic principles of implementation monetary regime. Financial and credit activity: problems of theory and practice, 2(23), 388-396. [Google Scholar] [CrossRef]

Kwilinski, A., \& Kuzior, A. (2020a). Cognitive technologies in the management and formation of directions of the priority development of industrial enterprises. Management Systems in Production Engineering, 28(2), 119-123. [Google Scholar] [CrossRef] Kwilinski, A., Zaloznova, Y., Trushkina, N., \& Rynkevych, N. (2020b). Organizational and Methodological Support for Ukrainian Coal Enterprises Marketing Activity Improvement. E3S Web of Conferences, 168, 00031. [Google Scholar] [CrossRef]

Kwilinski, A., Vyshnevskyi, O., \& Dzwigol, H. (2020c). Digitalization of the EU Economies and People at Risk of Poverty or Social Exclusion. Journal of Risk and Financial Management, 13(7), 142. [CrossRef]

Li, R., Sineviciene, L., Melnyk, L., Kubatko, O., Karintseva, O., \& Lyulyov, O. (2019). Economic and environmental convergence of transformation economy: the case of China. Problems and Perspectives in Management, 17(3), 233. [Google Scholar]

Lyulyov, O., Pimonenko, T., Chygryn, O., \& Palienko, M. (2018). Environmental Performance Index: relation between social and economic welfare of the countries. Environmental Economics, 9(3), 1. [Google Scholar]

Mills, R. W., \& Weinstein, B. (2000). Beyond shareholder value-Reconciling the shareholder and stakeholder perspectives. Journal of General Management, 25(3), 79-93. [Google Scholar] [CrossRef]

Miśkiewicz, R, \& Wolniak, R. (2020). Practical Application of the Industry 4.0 Concept in a Steel Company. Sustainability, 12(14), 5776. [CrossRef]

Mitchell, R. K., \& Agle, B. R. (1997, July). Stakeholder identification and salience: Dialogue and operationalization. In Proceedings of the International Association for Business and Society (Vol. 8, pp. 717-727). [Google Scholar] [CrossRef] 
0., Chygryn, Y., Bilan, A., Kwilinski. Stakeholders of Green Competitiveness: Innovative Approaches for Creating Communicative System

Palienko, M., \& Lyulyov, O. (2018). The impact of social factors on macroeconomic stability: empirical evidence for Ukraine and European Union countries. SocioEconomic Challenges, (2, Iss. 1), 103-116. [Google Scholar]

Pajak, K., Kvilinskyi, O., Fasiecka, O., \& Miśkiewicz, R. (2017). Energy security in regional policy in Wielkopolska region of Poland. Economics and Environment, 2(61), 122-138. Retrieved from https://www.ekonomiaisrodowisko.pl/uploads/eis 61/11_pajak.pdf Scholarl

Pfeffer, J., \& Jeffrey, P. (1998). The human equation: Building profits by putting people first. Harvard Business Press. [Google

Pimonenko, T., \& Lushyk, K. (2017). Green investing: EU experience for Ukraine. Bulletin of Sumy State University. Economy Ser, 3, 61-67. [Google Scholar] [CrossRef]

Pimonenko, T., Bilan, Y., Horák, J., Starchenko, L., \& Gajda, W. (2020). Green Brand of Companies and Greenwashing under Sustainable Development Goals. Sustainability, 12(4), 1679. [Google Scholar] [CrossRef]

Pimonenko, T., Chyhryn, O., \& Liulov O. (2018a). Green Entrepreneurship as an Integral Part of the National Economy Convergence. National Security \& Innovation Activities: Methodology. Policy and Practice: a monograph, 358 - 366. [Google Scholar] Pimonenko, T., Lyulyov, O., \& Chygryn, O. (2018b). Green investment marketing: a mechanism of collaboration between major stakeholders. Bulletin of Priazovsky State Technical University. Series: Economic Sciences, 1 (36), 214 - 220.

Pimonenko, T., Lyulyov, O., Chygryn, O., \& Palienko, M. (2018c). Environmental Performance Index: relation between social and economic welfare of the countries. Environmental Economics, 9(3), 1. [Google Scholar]

Plepys, A., Heiskanen, E., \& Mont, O. (2015). European policy approaches to promote servicizing. Journal of Cleaner Production, 97, 117-123. [Google Scholar] [CrossRef]

Porter, M. E., \& Van der Linde, C. (1995). Toward a new conception of the environment-competitiveness relationship. Journal of economic perspectives, 9(4), 97-118. [Google Scholar] [CrossRef]

Rosokhata, A., \& Sager, L. (2020). Individual issues of economic security: the study of the impact of changes in migration processes on countries economic and innovative development. Visnyk of Sumy State University, Economics series, 1, 62-74.

Rosokhata, A., Rybina O., Derykolenko, A., \& Makerska, V. (2020a). Improving the Classification of Digital Marketing Tools for the Industrial Goods Promotion in the Globalization Context. Research in World Economy, 11 (4). Special Issue, 42 - 52. [CrossRef

Saługa, P.W., Szczepańska-Woszczyna, K., Miśkiewicz, R., \& Chłąd, M. (2020). Cost of Equity of Coal-Fired Power Generation Projects in Poland: Its Importance for the Management of Decision-Making Process. Energies. 13(18), 4833. [CrossRef]

Savage, G. T., Nix, T. W., Whitehead, C. J., \& Blair, J. D. (1991). Strategies for assessing and managing organizational stakeholders. Academy of management perspectives, 5(2), 61-75. [Google Scholar] [CrossRef]

Savchenko, T., Basiurkina, N., Rodina, O., \& Kwilinski, A. (2019). Improvement of the Assessment Methods of Product Competitiveness of the Specialized Poultry Enterprises. Management Theory and Studies for Rural Business and Infrastructure Development, 41(1), 43-61. [CrossRef]

Scott, S. G., \& Lane, V. R. (2000). A stakeholder approach to organizational identity. Academy of Management review, 25(1), 43-62. [Google Scholar] [CrossRef]

Susniene, D., \& Vanagas, P. (2006). Development of stakeholder relationships by integrating their needs into organization's goals and objectives. Engineering economics, 48(3), 88-93. [Google Scholar]

Tkachenko, V., Kwilinski, A., Kaminska, B., Tkachenko, I., \& Puzyrova, P. (2019). Development and Effectiveness of Financial Potential Management of Enterprises in Modern Conditions. Financial and Credit Activity: Problems of Theory and Practice, 3(30), 85-94. [CrossRef]

Van Horn, C., Baumer, D., \& Gormley, W. (2001). Politics and Public Policy. Washington DC: Congressional Quarterly Press, 45 - 53. [Google Scholar]

Vovchak, O. D., Senyshch, P. M., \& Melnyk, T. V. (2019). «Purging» of the banking system: impacton the key performance indicators of banks. Financial and credit activity: problems of theory and practice, 1(28), 16-25. [Google Scholar] [CrossRef]

Yevdokimov, Y., Chygryn, O., Pimonenko, T., \& Lyulyov, O. (2018). Biogas as an alternative energy resource for Ukrainian companies: EU experience. Innovative Marketing, 14, 7 - 15. [Google Scholar]

Олена Чигрин, Ph.D., доцент, Сумський державний університет, Україна

Юрій Білан, Dr. Sc., профресор, Сумський державний університет, Україна

Олексій Квілінський, Dr. Sc., Лондонська академія науки і бізнесу, Великобританія

Стейкхолдери зеленої конкурентоспроможності: інноваційні підходи в створенні комунікаційних систем

Діяльність та взаємодія стейкхолдерів розвитку та просування зеленої конкурентоспроможності підприємств $є$ актуальними сьогодні і відіграють важливу роль для створення конкурентних переваг підприємств на ринку. Систематизація літературних джерел доводить, що економічна діяльність характеризується специфічними взаємовідносинами між широким колом зацікавлених сторін. При цьому ефективна комунікативна система може принести потенційну вигоду всім сторонам. Авторами відмічено, що у даному випадку самі стейкхолдери мають власні конкретні очікування щодо різних аспектів функціонування підприємств: організаційних, економічних, соціальних, екологічних тощо. Основною метою статті $\epsilon$ формування передумов для побудови системи комунікації зі стейкхолдерами для просування зеленої 
O., Chygryn, Y., Bilan, A., Kwilinski. Stakeholders of Green Competitiveness: Innovative Approaches for Creating Communicative System

конкурентоспроможності підприємств та оцінки зацікавленими сторонами наслідків діяльності компаній. В роботі використовуються наукові методи, засновані на логічному узагальненні та науковій абстракції для систематизації передумов формування системи комунікацій зелених конкурентних стейкхолдерів; типологзації стейкхолдерів зеленої конкурентоспроможності; формально-логічний для визначення детермінант та принципів ефективної співпраці зацікавлених сторін зеленої конкурентоспроможності. Для дослідження оцінки зацікавленими сторонами ефектів зеленої конкурентоспроможності було проведено багатовимірний аналіз масштабування та оцінено п'ять вимірів отриманих ефектів: задоволеність споживачів зеленими товарами; ефективність виробництва зелених товарів; якість зелених товарів та чисте виробництво; інституційне партнерство; вплив громади. Для масштабування відповідей в ході опитування використовувалася семибальна психометрична шкала Лікерта. Загальне опитування проводиться на основі даних п'яти країн: України, Польщі, Румунії, Словенії, Чехії та включає результати опитування 1236 стейкхолдерів. Результати оцінки показують, що у всіх групах (внутрішніх та зовнішніх) стейкхолдерів, працівники підприємств оцінюють результати екологічних стратегій як «успішні» - 22,3\% та громади, з іншої групи, - 7,45\%. Висновки стейкхолдерів є практично ідентичними. Таким чином, це свідчить про те, що процеси екологізації комунікацій із зацікавленими сторонами стають ширшими та залучають більше учасників. Результати дослідження створюють передумови для вдосконалення системи взаємодії зацікавлених сторін зеленої конкурентоспроможності.

Ключові слова: стейкхолдер, зелена конкурентоспроможність, взаємодія, партнерство стейкхолдерів, оцінка.

Manuscript received: 20.06 .2020

(C) The author(s) 2020. This article is published with open access at Sumy State University 